Article

\title{
Standardization of the Dimensions of a Portable Weighing Lysimeter Designed to Be Applied to Vegetable Crops in Mediterranean Climates
}

\author{
Manuel Soler-Méndez ${ }^{1}$, Dolores Parras-Burgos ${ }^{2, *} \mathbb{C}$, Estefanía Mas-Espinosa ${ }^{1}$, Antonio Ruíz-Canales ${ }^{3}$, \\ Diego S. Intrigliolo ${ }^{4}\left(\mathbb{D}\right.$ and José Miguel Molina-Martínez ${ }^{1}$ (D)
}

1 Agromotic Engineering and the Sea Research Group, Universidad Politécnica de Cartagena, 30202 Cartagena, Spain; manuel.ia@agrosolmen.es (M.S.-M.); masespinosa.estefania@gmail.com (E.M.-E.); josem.molina@upct.es (J.M.M.-M.)

2 Department of Structures, Construction and Graphic Expression, Universidad Politécnica de Cartagena, 30202 Cartagena, Spain

3 Engineering Department, Universidad Miguel Hernandez, 03312 Alicante, Spain; canales@umh.es

4 Irrigation Department, Centre for Applied Soil Science and Biology of the Segura (CEBAS), of the Spanish National Research Council (CSIC), Campus Universitario de Espinardo, Espinardo, 30100 Murcia, Spain; dintri@cebas.csic.es

* Correspondence: dolores.parras@upct.es; Tel.: +34-868-071-184

\section{check for} updates

Citation: Soler-Méndez, M.; Parras-Burgos, D.; Mas-Espinosa, E.; Ruíz-Canales, A.; Intrigliolo, D.S.; Molina-Martínez, J.M.

Standardization of the Dimensions of a Portable Weighing Lysimeter Designed to Be Applied to Vegetable Crops in Mediterranean Climates. Sustainability 2021, 13, 2210. https:// doi.org/10.3390/su13042210

Academic Editor: Domenico Ronga

Received: 2 February 2021

Accepted: 15 February 2021

Published: 18 February 2021

Publisher's Note: MDPI stays neutral with regard to jurisdictional claims in published maps and institutional affiliations.

Copyright: (c) 2021 by the authors. Licensee MDPI, Basel, Switzerland. This article is an open access article distributed under the terms and conditions of the Creative Commons Attribution (CC BY) license (https:// creativecommons.org/licenses/by/ $4.0 /)$.
Abstract: The progress made in developing information and communication technologies (ICTs) and the fact that water resources are becoming increasingly scarce make precision agriculture a very valuable tool for efficient and sustainable crop management, particularly for irrigation and fertilisation. In line with this, the water balance estimate is considered one of the most accurate methods for estimating crops' water requirements. The Agromotic Engineering and Sea Research Group of the Universidad Politécnica de Cartagena (Spain) has worked in this direction to obtain portable weighing lysimeters with improved functions compared to traditional measurement systems. This study analysed the most important vegetable crops in south-eastern Spain to standardise suitable dimensions so that these portable weighing lysimeters can monitor practically all of today's vegetable and herbaceous crops in Mediterranean climates. The dimensions established for the cultivation tank are $150 \mathrm{~cm}$ long, $45 \mathrm{~cm}$ wide, and $50 \mathrm{~cm}$ deep, with an equipment resolution of up to $0.09 \mathrm{~mm}$ expressed as water lamina. The validation over seven irrigation events established that the structural system achieved here allows precise monitoring of the water exchanges produced in the cultivation tank, so this portable weighing lysimeter can be useful for the efficient management of fertigation.

Keywords: vegetable crops; precision agriculture; water balance; weighing lysimeter; sustainable fertigation management

\section{Introduction}

Agriculture is essential for the supply of food to society, especially with the production of fruits and vegetables. In Spain, fruit and vegetable production represents $20 \%$ of the total European production (mean between 2013 and 2017 [1]), which certainly demonstrates how important Spanish agriculture is in this sector. The value of Spanish vegetable production is similar to that of fruit production, although the surface area employed for vegetable production is half that for fruit production [1]. These data show that Spanish vegetable crops are highly productive, and south-eastern (SE) Spain sends the biggest amounts of vegetables to Europe, with 70\% of all vegetable exports coming from Spain [2].

Agricultural production will face certain challenges in the coming years that must be overcome to attend to the growing population, and there is no alternative but to be more productive in a scenario where natural resources become increasingly scarce and climate change takes place $[3,4]$. Hence, investments in the improvement of water control and 
management are being prioritised [5]. Many studies are being conducted to obtain tools that achieve water control in order to promote efficient water management, and these are mostly supported through the use of information and communication technologies (ICTs). The use of ICTs to manage horticulture with precision agriculture techniques can help the sector to move towards long-standing sustainable management and to meet the coming environmental challenges [6-13].

Irrigation management is a complex activity that is influenced by many factors that are closely related to the soil-plant-atmosphere continuum. Other factors are also important in deciding the irrigation criteria, such as the quality of the irrigation water or the crops nutrition. Pressurized irrigation allows water control systems to be established for efficient management. Soil moisture sensors are used to obtain signals from the plant root zone that can be read by data acquisition equipment, and actuators are used to control the irrigation system based on the parameterized criteria [14]. Generally, with the exception of bottom fertilizer applications, fertilizers are applied to irrigation water regardless of the irrigation method used. Therefore, fertilization must be considered to manage irrigation.

In light of the above, it follows that irrigation is directly related to the supply of nutrients to crops. Therefore, it is reasonable to deduce that, to achieve efficient water management during irrigation, it is necessary to control the entire water and nutritional balance [15-18]. The objective of efficient irrigation control is twofold: (1) to supply the minimum dose of water necessary to satisfy the water needs of a crop without increasing the salinity of the soil; (2) to achieve the contribution of nutrients with minimal leaching to contain environmental pollution. Therefore, it is essential to monitor all components of the water balance and how the water quality evolves in both the nutrient solution and the leaching to deeper layers (drainage) [19,20].

The weighing lysimeter is a useful tool used by many researchers to accurately measure the use of water in crops [21-26]. A weighing lysimeter can quantify water inputs and losses, and it also quantifies losses due to drainage. Thus, by means of nutritional analysis of the water input and the drained water, a nutritional balance can be established [27]. In recent years, the Agromotic Engineering and Sea Research Group of the Universidad Politécnica de Cartagena (Spain) has worked on obtaining accurate, robust, practical, low-cost, and portable weighing lysimetry equipment by progressively adding functions that make it extremely useful for knowing how a crop develops in terms of water and nutritional uses [28-31].

The research objective is to obtain a useful and standard tool based on the weighing lysimeter in order to make the newly developed weighing lysimeter more versatile and commercial. For this purpose, this study was based on the analysis of the main vegetable crops (including herbaceous crops) in order to define the most suitable dimensions and functions. The portable nature of the weighing lysimeter is based on the fact that, with little investment, it can be relocated in order to monitor different parts of a farm after the end of a crop cycle.

\section{Materials and Methods}

In order to obtain the dimensions of the proposed portable weighing lysimeter and to standardise a model for its commercial use on vegetable farms, a study was conducted on the most representative crops in SE Spain. The most relevant dimensional parameters for defining the equipment were established, and the weighing system's features were analysed.

\subsection{Crops under Study}

As vegetable crops are extremely important in Spain, especially in SE Spain, the production of the most important vegetables grown in the Murcia Region and neighbouring regions was analysed. Using the Regional Farming Statistics of the Regional Ministry of Agriculture, Livestock, and Fishing of the Spanish Murcia Region Autonomous Community (Spain) [32], data on the production of the 10 most productive crops were collected for the 2011-2017 period (Table 1). The selected crops were, in order of greater to lesser 
importance: lettuce, tomato, watermelon, melon, broccoli, pepper, artichoke, celery, onion, and courgette. To confirm if the choice of crops was correct, the production of all $10 \mathrm{crops}$ was compared to the total crop production for each year. The obtained results are found in Table 2.

Table 1. Evolution of the production (in tonnes) of the main vegetable crops in the Murcia Region [32].

\begin{tabular}{cccccccc}
\hline Crops & $\mathbf{2 0 1 1}$ & $\mathbf{2 0 1 2}$ & $\mathbf{2 0 1 3}$ & $\mathbf{2 0 1 4}$ & $\mathbf{2 0 1 5}$ & $\mathbf{2 0 1 6}$ & $\mathbf{2 0 1 7}$ \\
\hline Lettuce & 333.1 & 344.6 & 370.3 & 375.6 & 378.6 & 392.8 & 453.1 \\
Tomato & 311.1 & 289.4 & 298.9 & 323.5 & 172.0 & 210.0 & 217.2 \\
Watermelon & 118.8 & 128.8 & 137.5 & 141.3 & 190.5 & 288.5 & 250.2 \\
Melon & 219.8 & 226.4 & 223.8 & 214.2 & 189.0 & 182.0 & 213.6 \\
Broccoli & 164.6 & 172.5 & 207.0 & 213.4 & 202.7 & 208.3 & 203.9 \\
Pepper & 111.0 & 99.7 & 107.3 & 126.5 & 124.2 & 143.4 & 176.4 \\
Artichoke & 78.3 & 86.0 & 86.6 & 111.1 & 90.0 & 105.5 & 101.0 \\
Celery & 43.1 & 40.1 & 42.4 & 58.0 & 59.5 & 60.6 & 62.3 \\
Onion & 28.2 & 35.1 & 40.3 & 43.1 & 47.5 & 53.5 & 40.9 \\
Courgette & 8.8 & 9.5 & 10.5 & 8.7 & 6.9 & 18.2 & 15.2 \\
Total & 1504.7 & 1521.4 & 1614.0 & 1701.6 & 1538.3 & 1754.2 & 1831.4 \\
\hline
\end{tabular}

Table 2. Relative importance in relation to the production quantity of the main vegetable crops in the Murcia Region.

\begin{tabular}{cccccccc}
\hline Crops & $\mathbf{2 0 1 1}$ & $\mathbf{2 0 1 2}$ & $\mathbf{2 0 1 3}$ & $\mathbf{2 0 1 4}$ & $\mathbf{2 0 1 5}$ & $\mathbf{2 0 1 6}$ & $\mathbf{2 0 1 7}$ \\
\hline Lettuce & $22.1 \%$ & $22.6 \%$ & $22.9 \%$ & $22.1 \%$ & $24.6 \%$ & $22.4 \%$ & $24.7 \%$ \\
Tomato & $20.7 \%$ & $19.0 \%$ & $18.5 \%$ & $19.0 \%$ & $11.2 \%$ & $12.0 \%$ & $11.9 \%$ \\
Watermelon & $7.9 \%$ & $8.5 \%$ & $8.5 \%$ & $8.3 \%$ & $12.4 \%$ & $16.4 \%$ & $13.7 \%$ \\
Melon & $14.6 \%$ & $14.9 \%$ & $13.9 \%$ & $12.6 \%$ & $12.3 \%$ & $10.4 \%$ & $11.7 \%$ \\
Broccoli & $10.9 \%$ & $11.3 \%$ & $12.8 \%$ & $12.5 \%$ & $13.2 \%$ & $11.9 \%$ & $11.1 \%$ \\
Pepper & $7.4 \%$ & $6.5 \%$ & $6.6 \%$ & $7.4 \%$ & $8.1 \%$ & $8.2 \%$ & $9.6 \%$ \\
Artichoke & $5.2 \%$ & $5.6 \%$ & $5.4 \%$ & $6.5 \%$ & $5.9 \%$ & $6.0 \%$ & $5.5 \%$ \\
Celery & $2.9 \%$ & $2.6 \%$ & $2.6 \%$ & $3.4 \%$ & $3.9 \%$ & $3.5 \%$ & $3.4 \%$ \\
Onion & $1.9 \%$ & $2.3 \%$ & $2.5 \%$ & $2.5 \%$ & $3.1 \%$ & $3.1 \%$ & $2.2 \%$ \\
Courgette & $0.6 \%$ & $0.6 \%$ & $0.7 \%$ & $0.5 \%$ & $0.4 \%$ & $1.0 \%$ & $0.8 \%$ \\
Relative importance & $94.2 \%$ & $94.1 \%$ & $94.5 \%$ & $95.0 \%$ & $95.0 \%$ & $94.8 \%$ & $94.7 \%$ \\
\hline
\end{tabular}

After deciding which vegetable crops were the most important ones for the Murcia Region, the production of these 10 selected crops, which roughly represented $95 \%$ of all vegetable production, was compared to corroborate if they were also important when consulting the statistical data from the neighbouring Regional Governments of the Valencian Community, Andalusia, and Castilla la Mancha (Spain). Table 3 shows the production data for these vegetable crops in relation to the total vegetable production in each region.

Table 3. Relative importance in relation to the production quantity of the main vegetable crops in neighbouring regions.

\begin{tabular}{cccc}
\hline Crops & $\begin{array}{c}\text { Valencian Community } \\
\text { (2017) [33] }\end{array}$ & $\begin{array}{c}\text { Castilla la Mancha } \\
\mathbf{( 2 0 1 7 )}[34]\end{array}$ & $\begin{array}{c}\text { Andalusia (2017) } \\
{[35]}\end{array}$ \\
\hline Lettuce & $8.1 \%$ & $0.0 \%$ & $4.3 \%$ \\
Tomato & $9.3 \%$ & $0.0 \%$ & $34.3 \%$ \\
Watermelon & $9.2 \%$ & $0.0 \%$ & $10.2 \%$ \\
Melon & $5.6 \%$ & $13.7 \%$ & $2.2 \%$ \\
Broccoli & $6.3 \%$ & $0.0 \%$ & $1.0 \%$ \\
Pepper & $7.4 \%$ & $0.0 \%$ & $12.2 \%$ \\
Artichoke & $7.6 \%$ & $0.0 \%$ & $0.1 \%$ \\
Celery & $2.5 \%$ & $0.0 \%$ & $0.1 \%$ \\
Onion & $10.9 \%$ & $49.5 \%$ & $2.2 \%$ \\
Courgette & $2.2 \%$ & $0.0 \%$ & $7.5 \%$ \\
Relative importance & $69.3 \%$ & $63.2 \%$ & $74.3 \%$ \\
\hline
\end{tabular}


The intention of the crop choice was to learn both taxonomic and agronomic characteristics in order to know the suitable dimensions for a cultivation tank of a commercial portable weighing lysimeter. Therefore, the taxonomic and agronomic characteristics of all of the selected crops were studied [36-41]. According to the obtained information, Table 4 shows the main crop characteristics (average values) that can affect the dimensions of portable weighing lysimetry equipment.

Table 4. Main characteristics of the most important crops in south-eastern (SE) Spain (average values) [36-41].

\begin{tabular}{cccc}
\hline Crops & Planting Distance $\mathbf{( c m )}$ & Row Spacing $(\mathbf{c m})$ & Deep Root $(\mathbf{c m})$ \\
\hline Lettuce & $20-30$ & 90 & 25 \\
Tomato & 50 & 150 & 50 \\
Watermelon & 200 & $180-200$ & 50 \\
Melon & 50 & 200 & 50 \\
Broccoli & $35-40$ & 90 & 50 \\
Pepper & 50 & 100 & 50 \\
Artichoke & $75-80$ & 120 & 45 \\
Celery & $25-30$ & 90 & 30 \\
Onion & 10 & 10 & $<50$ \\
Courgette & 75 & 150 & 30 \\
\hline
\end{tabular}

To be installed, portable weighing lysimetry equipment is buried below a crop line and left on the farm. Therefore, its dimensions must allow it to be left and integrated with all of the selected crops. To this end, the mechanisation and production systems of the different crops, especially lettuce and melon, were analysed, but this can also be done with the other crops.

Figure 1 illustrates the normal lettuce production system, which includes crop beds that are commonly known as "estrechas/narrow beds". They measure $18 \mathrm{~cm}$ high and $55 \mathrm{~cm}$ wide (top), with a $90 \mathrm{~cm}$ distance between the two axes of two parallel consecutive beds. They are inclined in such a way that each slope is horizontally projected by $12.5 \mathrm{~cm}$, and have a $10 \mathrm{~cm}$ wide bearing base. This production system is commonplace for lettuce, broccoli, and celery, and is sometimes used for onion. At the top, two rows of plants are arranged per bed, except for onion, which is laid in more rows.
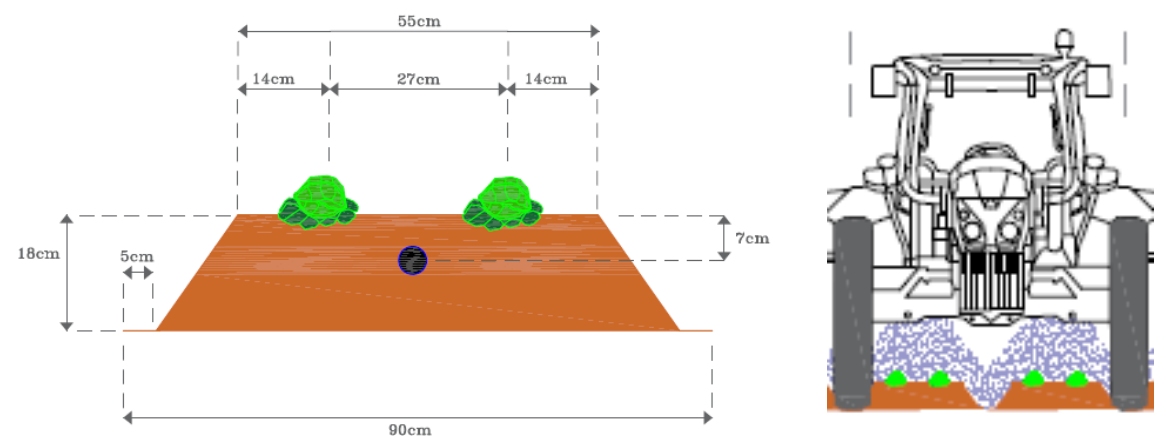

Figure 1. Scheme of the standardization of the mechanised production of lettuce in narrow crop beds. On the right, it is shown how the machine operates, leaving two complete narrow crop beds between its wheels; on the left are the details of the dimensions of a narrow crop bed.

Figure 2 depicts the baby lettuce production system with crop beds that are frequently called "anchas/wide beds". They are $18 \mathrm{~cm}$ high and $140 \mathrm{~cm}$ wide at the top, with a $180 \mathrm{~cm}$ distance between the axes of two parallel consecutive beds, and the slopes are inclined in such a way that each slope is horizontally projected by $15 \mathrm{~cm}$, with a $10 \mathrm{~cm}$ wide bearing base. This production system is mainly used for baby lettuce, onion, or baby leaf. For baby 
lettuce, it is common to use six rows per bed, or between 8 and 12 rows for onion, while baby leaf is grown by being directly sown all over the surface.
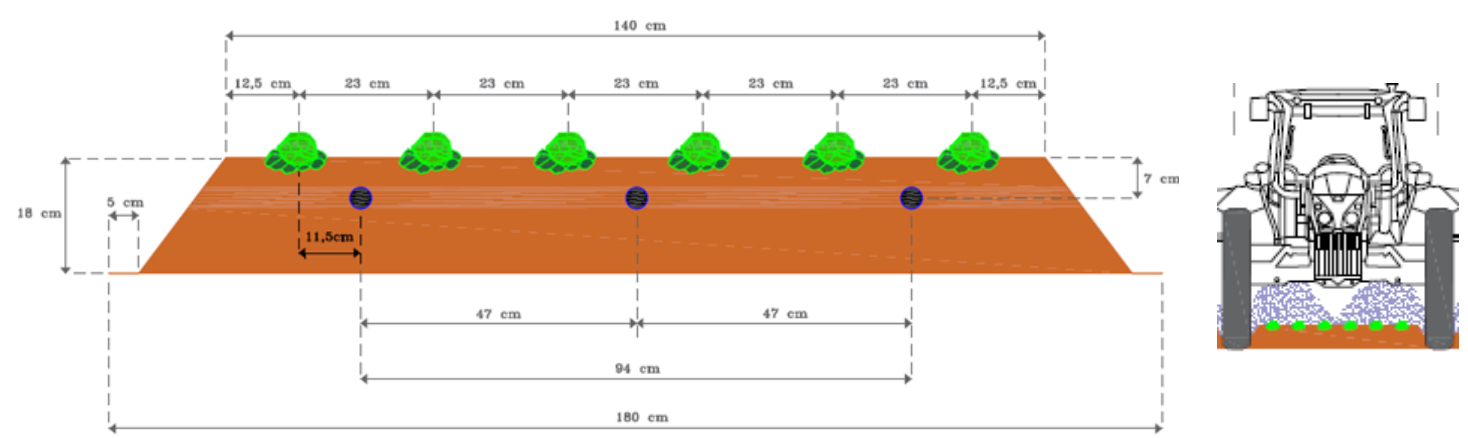

Figure 2. Scheme of the standardisation of the mechanised production of lettuce in wide crop beds. On the right, it is shown how the machinery circulates, leaving a complete wide crop bed between its wheels; on the left are the details of the dimensions of a wide crop bed.

Figure 3 shows the melon production system, which is flat with no crop beds. A separation between crop lines of $180 \mathrm{~cm}$ is standard practice. Therefore, this production system can be extended to any crop that is grown flat without crop beds (tomato, watermelon, pepper, artichoke, courgette, etc.).
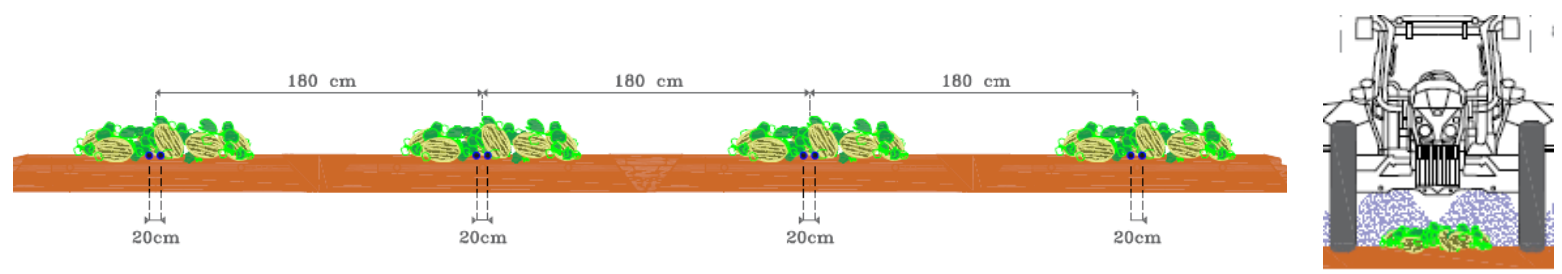

Figure 3. Scheme of the standardization of the mechanised production of melon. On the right, it is shown how the machine operates, leaving a crop line-not a crop bed-between its wheels. The details of the dimensions of the plantation frames without a crop bed are shown on the left.

All three figures reflect the mechanisation scheme so that, in depending on the production system, two narrow crop beds, one wide crop bed, or a row of crops can coincide below the tractor.

\subsection{Description of the Portable Weighing Lysimeter}

Having obtained all of the information about the characteristics of the plants and farming systems, the three characteristic dimensions of the cultivation tank for the portable weighing lysimeter (height, length, and depth) were defined. To this end, the main portable weighing lysimetry equipment structures were defined (Figure 4).

(a) Main structure (MS): The portable weighing lysimeter was designed to be buried and to support a portion of soil that is to be monitored. To do so, a structure is needed that can house all the components used to quantify the soil + water + plant set mass and drainage. This structure must be such that the earth surrounding it does not apply any force on the cultivation tank's weighing system. This structure acts as a covering for all of the equipment, is made of stainless steel, and is totally airtight, so neither capillary rises nor high phreatic levels interfere.

(b) Support structure (SS): This structure supports the weight of the cultivation tank with the four load cells that comprise it. It must also independently support deep percolation drainage, which is quantified by means of a tank that holds this volume and is supported by a load cell that is independent of the others. This structure is anchored to the interior of the MS, and was devised to independently hold the 
cultivation tank to ensure its manoeuvrability. All of the elements required for the portable weighting lysimetry equipment to work properly are considered in this structure.

(c) Cultivation tank (CT): This structure houses the portion of soil to be monitored. The number of plants that it contains depends on the planting framework. Its dimensions must be big enough for it to hold any type of vegetable or herbaceous crop, and it is integrated into farms depending on the system that they have set up. It is designed with stainless steel. It has several reinforcements that can support the load, as well as a deep percolation drainage system. This system continues with the drainage tank, which is the part of the equipment that quantifies the drainage.

(d) Drainage tank (DT): This quantifies the deep percolation drainage with a load cell and qualifies it with an electric conductivity sensor.

(e) Electrical control panel: This allows the registration of the information from the two weighing systems (the cultivation tank and the drainage tank) in data acquisition equipment. The weighing system of the cultivation tank has four load cells that are connected in parallel in a summing box so that a shielded six-wire line leads to the first weighing indicator. The other weighing system, that of the drainage tank, has one load cell connected directly to the second weighing indicator. Both read the load cells with a resolution of 24 bits and are connected to the datalogger CAMPBELL SCI. CR300 by MODBUS RTU RS485. All of the operating cycle management algorithms of the complete lysimetry system are embedded in the datalogger in order to be able to accurately quantify both the variations that occur in the culture tank and those that occur in the drainage tank.

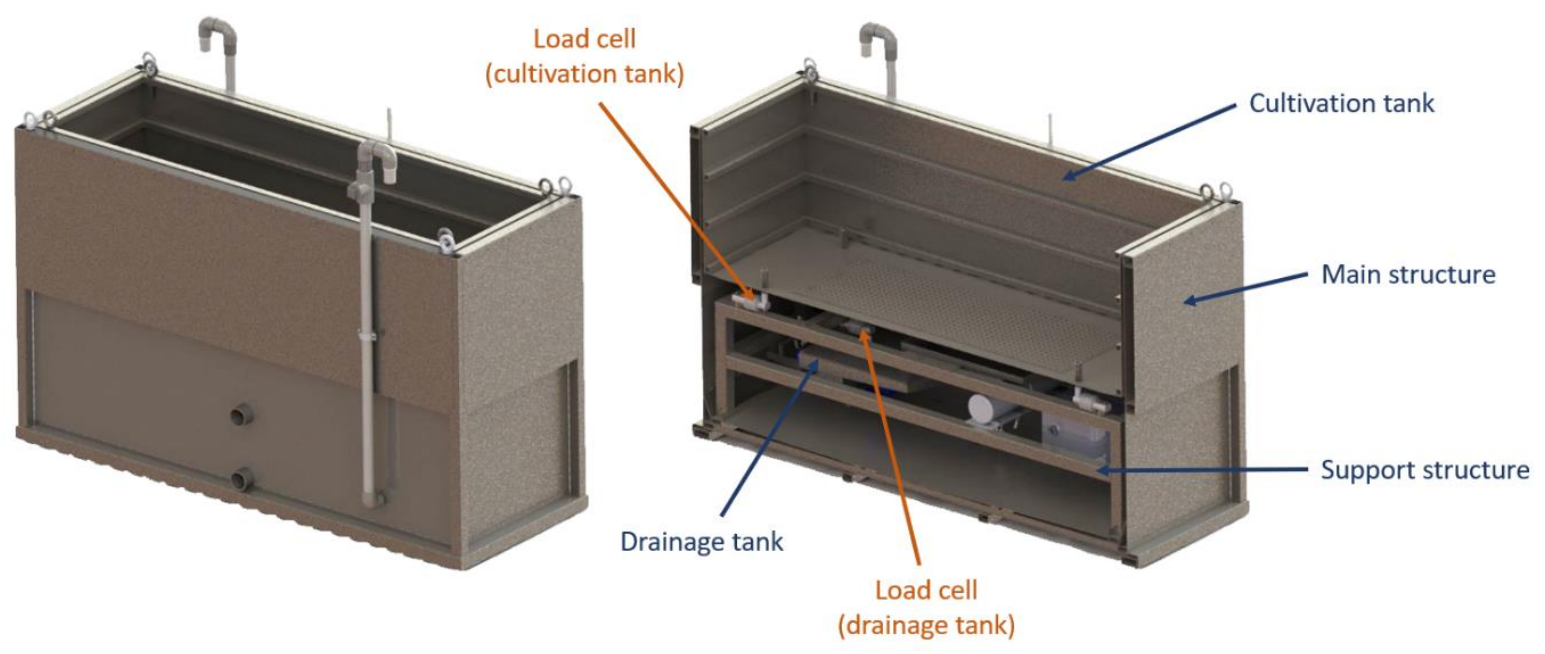

Figure 4. Main portable weighing lysimeter structures.

\subsection{The Cultivation Tank's Dimensional Characteristics}

Having determined the portable weighing lysimetry equipment's MS, the $\mathrm{CT}^{\prime}$ 's dimensions, which are closely related to the dimensions of the complete equipment, were calculated:

(a) Equipment width: The equipment must be able to fit inside any crop system and must be adapted to the production system. For this reason, the most limiting production system is the narrow crop bed type. To be able to fit the portable weighing lysimetry equipment in a narrow crop bed, the maximum width must be $55 \mathrm{~cm}$ so that it correctly fits inside its top. Thus, the main structure's (external) width (outer dimensions) measures $55 \mathrm{~cm}$. Bearing the portable weighing lysimeter's structural features in mind, we find that:

- $\quad$ The MS's thickness will be $2 \mathrm{~cm}$ all around its perimeter.

- $\quad$ The CT's thickness will be $2 \mathrm{~cm}$ all around its perimeter. 
The required gap between the MS and the CT will be $1 \mathrm{~cm}$ all around its perimeter in order to avoid effects on readings from both elements rubbing against one another.

Therefore, the CT's width (inner dimensions) will be the difference between the MS's width, less twice the sum of the thicknesses of the MS and the CT, plus the gap between both:

- Inner CT width $=55-2 \times(2+2+1)=45 \mathrm{~cm}$.

(b) Equipment length: This distance must allow at least two plants to be planted inside the equipment. By considering the planting distance set out in Table 4, the planting distance of one crop tends to be $200 \mathrm{~cm}$; for the established portable weighing lysimetry equipment design, increasing its length to $400 \mathrm{~cm}$ would not be technically or economically feasible. Thus, an exception was made for watermelon because only one plant would be monitored, and the following crops were considered, whose frames $(75 \mathrm{~cm})$ are the most separate: artichoke or courgette. In this way, the inner CT length would result from multiplying the minimum number of plants to be monitored (two plants) by the planting distance between both along one line $(75 \mathrm{~cm})$ :

- Inner CT length $=75 \times 2=150 \mathrm{~cm}$.

The total MS length (outer dimensions) is the sum of the inner CT length, plus twice the sum of the thicknesses of the MS and the CT, plus the gap between the two:

- $\quad$ Outer MS length $=150+2 \times(2+2+1)=160 \mathrm{~cm}$.

(c) Equipment depth: The CT must be able to house the root systems of crops with more root development. The literature offers many values for this parameter, and Table 4 summarises the mean depth values for each crop. According to this information, the maximum CT depth must be $50 \mathrm{~cm}$. Performing deep percolation drainage towards the DT's draining channels must take place at the bottom of the equipment. To this end, a $5 \mathrm{~cm}$ slope was considered so that the depth all along the CT's perimeter would be the difference in the maximum depth, less the margin determined as the drainage slope:

- Maximum CT depth $=50 \mathrm{~cm}$.

- Minimum CT depth $=50-5=45 \mathrm{~cm}$.

To determine the CT's depth, the load cell dimensions were also taken into account to avoid compromising the solving data due to excess mass.

\subsection{Weighing System Calculations}

The calculations that are performed to specify the $\mathrm{CT}^{\prime}$ 's depth and to define the weighing system of the equipment with the load cellsare then determined.

(a) Estimating masses: The masses estimated to support the CT's measurement system are:

- $\quad$ CT mass $=70 \mathrm{~kg}$.

- $\quad$ Established soil density $=2650 \mathrm{~kg} \cdot \mathrm{m}^{-3}$ [42]. A $30 \%$ reduction is applied to estimate the apparent density owing to porosity: $2650 \times(1-0.3)=1855 \mathrm{~kg} \cdot \mathrm{m}^{-3}$.

- Mean CT depth: This is calculated as the average between the maximum and minimum depths: $(0.5-0.45) / 2=0.475 \mathrm{~m}$.

- CT volume: This is the product of the inner length, inner width, and the mean depth: $1.5 \times 0.45 \times 0.475=0.321 \mathrm{~m}^{3}$.

- $\quad$ Contained soil mass: This is the product of the CT's volume and apparent density: $0.321 \times 1855=595 \mathrm{~kg}$.

- Dead weight: This is the load that, despite it being measured by load cells, is not of any interest for the process. In this case, the dead weight is determined by the CT's weight plus the contained soil mass because the values of 
interest are those of the interchange water mass and the plant material mass: $70+595=665 \mathrm{~kg}$.

- Plant material mass: This depends on the crop that is used, but an initial baseline is taken at $50 \mathrm{~kg}$.

- Soil water mass: The amount of water that soil can contain while keeping up to field capacity. Initially, field capacity is estimated as $25 \%$ of volumetric humidity, and the water density is taken as $1000 \mathrm{~kg} \cdot \mathrm{m}^{-3}: 0.321 \times 0.25 \times 1000=80 \mathrm{~kg}$.

- Interchange water mass: This is the additional mass that results from water from inputs such as precipitation, torrents, or irrigation, and it is initially estimated as $10 \mathrm{~kg}$.

- Total water mass: This is the sum of the soil water mass and the interchange water mass: $80+10=90 \mathrm{~kg}$.

- Staking mass: For certain creeping crops, such as peppers and tomatoes, staking systems are required for separating growth due to the plant material inside the lysimeter. To avoid plants being staked in the equipment's outer structures, a staking system is joined only to the CT: $15 \mathrm{~kg}$.

- $\quad$ Accidental overload: Sometimes, the lysimeter may have to support a load that can overexert load cells. This must be taken into account by estimating the load to be $100 \mathrm{~kg}$. Accidental overloads can be understood as the footfalls of workers and/or animals or farming practises, such as pruning, weeding, harvesting, fertilizer, fumigation, etc.

(b) Scale definition: For scale calculations, the total mass and supporting mass are considered:

- Total mass for the scale: This is the sum of all of the previously estimated masses, which are the dead weight plus the plant material mass and the total water mass, as well as the staking mass and accidental overload: $665+50+90$ $+15+100=920 \mathrm{~kg}$.

- $\quad$ Number of scale supports = four units.

- Support mass: Theoretically, this is the mass that each support withstands, and it is equal if correctly levelled and fitted. It is the ratio between the total mass and the number of supports: $920 / 4=230 \mathrm{~kg}$.

(c) The cell's minimum nominal capacity: This is the minimum nominal capacity that the load cell must have for readings to be correct. It is calculated by applying a safety coefficient to the previously calculated support mass, whose value lies between 1.25 and 2.5. The contemplated factor is 1.25 after considering the equipment's accidental overloads and maximum possible resolution for quantifying the water balance: $230 \times 1.25=287 \mathrm{~kg}$.

(d) Choice of load cell: Albeit somewhat limited, a load cell with a $300 \mathrm{~kg}$ nominal capacity can be placed to support the maximum possible resolution; nevertheless, a load cell with a $500 \mathrm{~kg}$ nominal capacity is suitable so that equipment is more robust and less sensitive to overload breakdowns. The following calculations were performed, and they show that the resolution is transferred to the water lamina unit to extrapolate the results to crops outside the weighing lysimeter. To obtain the parameter $\mathrm{e}_{\mathrm{min}}$, which indicates the resolution that the scale is capable of offering, two forms of calculation were considered.

i. Calculating the parameter $\mathrm{e}_{\min }$ with the fraction $\mathrm{V}_{\min }$ :

- Nominal capacity fractions: This is the number of fractions into which the cell load's nominal capacity can be divided.

- Fraction $\mathrm{V}_{\min }$ : This is the minimum fraction value of a load cell, which is the ratio between its nominal capacity and the nominal capacity fractions. Scale division step: This is the product of the fraction Vmin and the square root of the number of supports, and is equivalent to the scale's resolution. 
This parameter can be taken as $\mathrm{e}_{\min }$ (rep), which is obtained with the scale's resolution.

ii. Calculating the $\mathrm{e}_{\min }$ parameter by means of linearity: We previously indicated that the scale has a dead weight that is used to quantify a load, and both magnitudes are supported by the set of load cells. This is a peculiar scale given the weighing lysimeter equipment's features, as the proportion of dead weight is much higher than the load to be quantified. In this case, the dead weight is estimated as the CT's mass plus the contained soil mass, which is much higher than the mass to be quantified for accurate irrigation management purposes, i.e., specifically, the interchange water mass (mostly irrigation or rainfall, drainage, and evapotranspiration). Thus, the scale is used to quantify less than $1 \%$ of its nominal capacity, and its resolution is also sufficient.

- The maximum load for exact quantification is equivalent to the interchange water mass $=10 \mathrm{~kg}$.

- $\quad$ The $\mathrm{n}_{\mathrm{lc}}$ parameter value of the load cell is 3000 .

With these data, the $e_{\min }$ parameter (lin) is the ratio between the maximum load to be quantified and the $\mathrm{n}_{\mathrm{lc}}$ value, irrespectively of the nominal capacity of the employed cell.

$$
\text { - } \quad \mathrm{e}_{\min }(\mathrm{lin})=10 / 3000=0.003 \mathrm{~kg} \text {. }
$$

iii The $e_{\min }$ parameter's value: This is the maximum value that results from the two calculation methods. Table 5 offers the results of the calculations performed for the two nominal capacities of the load cell to be chosen.

(e) The lysimeter's resolution: This magnitude, which is expressed through water lamina, is interesting for validation of the potential of the tool developed by our research group. It relates the previously calculated resolution ( $\mathrm{e}_{\min }$ parameter) to the lysimeter's surface, specifically that of the CT. With this unit, data can be extrapolated to other plots.

- $\quad$ CT surface: This is the product of the CT's inner length and width: $1.5 \times 0.45$ $=0.675 \mathrm{~m}^{2}$.

Table 5. Calculations of characteristic scale parameters to choose the nominal capacity of the load cells.

\begin{tabular}{lcl}
\hline Parameter & Load Cell $\mathbf{3 0 0} \mathbf{~ k g}$ & Load Cell $\mathbf{5 0 0 ~} \mathbf{~ k g}$ \\
\hline \multicolumn{2}{l}{ Calculation of the $\mathbf{e}_{\text {min }}$ parameter through fraction $\mathbf{V}_{\text {min }}$} \\
\hline Fractions of nominal capacity & 10,000 & 10,000 \\
Nominal capacity of load cells & $300 \mathrm{~kg}$ & $500 \mathrm{~kg}$ \\
Fraction $\mathrm{V}_{\text {min }}$ & $30 \mathrm{~g}$ & $50 \mathrm{~g}$ \\
$\mathrm{e}_{\text {min }}(\mathrm{rep})=$ resolution & $60 \mathrm{~g}$ & $100 \mathrm{~g}$ \\
\hline Calculation of the $\mathbf{e}_{\text {min }}$ parameter through linearity & \\
\hline Maximum load to be quantified & $10 \mathrm{~kg}$ & $10 \mathrm{~kg}$ \\
$\mathrm{n}_{\mathrm{lc}}$ & 3000 & 3000 \\
$\mathrm{e}_{\text {min }}($ lin) & $3 \mathrm{~g}$ & $3 \mathrm{~g}$ \\
\hline Final result for $\mathbf{e}_{\text {min }}$ & $100 \mathrm{~g}$ \\
\hline $\mathrm{e}_{\text {min }}$ & $60 \mathrm{~g}$ & \\
\hline
\end{tabular}

Based on the density established for water, which was previously defined, and the equivalence of $1 \mathrm{~mm}$ water lamina $=1 \mathrm{~L} \cdot \mathrm{m}^{-2}$, the lysimeter's resolution, which is expressed through the water lamina, is the ratio between the $\mathrm{e}_{\min }$ parameter (in $\mathrm{kg}$ ) and the surface (in $\mathrm{m}^{2}$ ).

Table 6 shows the calculation of the lysimeter's resolution according to the selected nominal capacity of the load cell. 
Table 6. Calculation of characteristic scale parameters to choose the nominal capacity of load cells.

\begin{tabular}{lll}
\hline Parameter & Load Cell, $300 \mathrm{~kg}$ & Load Cell, $500 \mathrm{~kg}$ \\
\hline Weighing lysimeter resolution & $0.09 \mathrm{~mm}$ & $0.15 \mathrm{~mm}$ \\
\hline
\end{tabular}

\subsection{Previous Experiences}

Studies published by the Agromotic Engineering and Sea Research Group (Universidad Politécnica de Cartagena, Spain) show that weighing lysimetry equipment is effective for monitoring the water balance of a crop $[18,28]$. The designs prior to the last development were able to adequately record variations in the cultivation tank and in the drainage tank; however, they lacked robustness and practicality. Hence came the idea of trying to improve the design to solve problems such as the integration of cultivation in different exploitation and mechanisation systems, facilitating maintenance work, or avoiding problems due to rising water tables. Then, starting from a system that was already capable of quantifying the water inlets and outlets of the cultivation tank and quantifying the drainage, the following structural changes were made:

(a) A catchment tank for the water drained by the culture tank was incorporated with the aim of making it independent from its control solenoid valve, thus facilitating maintenance work.

(b) The perimeter structure was waterproofed to avoid being affected by rises in the water table.

(c) The dimensions were modified to be able to adapt to the majority of vegetable and herbaceous crops.

Therefore, the validation of the standard equipment focused on recognising that the weighing system of the culture tank, which is the one that was finally modified, was able to adequately reflect small water exchanges inside the tank.

\subsection{Validating the Weighing System}

In order to validate the prototype, a functional trial was considered with pepper crops grown in greenhouses. After approximately 40 post-transplant days, seven irrigation times without drainage were analysed. During each irrigation time, $10 \mathrm{~min}$ of verification were used halfway through the irrigation to ensure that the irrigation fitting's water regime was stable. The final and initial CT weight values were compared to find the increase in quantity by taking the water density as $1000 \mathrm{~g} \cdot \mathrm{L}^{-1}$.

Variations in weight on the days immediately before and after the sampling period, as well as at the same time, were analysed to check if evapotranspiration, albeit negligible, took place at these times. Even so, any variation in CT weight was taken as being due to irrigation.

The following variables can be defined:

i. $\quad$ CT weight at the start of the sampling period, $\mathrm{CT}_{\mathrm{i}}$, expressed in $\mathrm{g}$.

ii. $\quad \mathrm{CT}$ weight at the end of the sampling period, $\mathrm{CT}_{\mathrm{f}}$, expressed in $\mathrm{g}$.

iii. Variation in $\mathrm{CT}$ weight during the sampling period, $\mathrm{CT}_{\mathrm{ap}}$, expressed in $\mathrm{g}$, which is equivalent to the water volume given in $\mathrm{mL}$.

$$
\mathrm{CT}_{\mathrm{ap}}=\mathrm{CT}_{\mathrm{f}}-\mathrm{CT}_{\mathrm{i}}
$$

Transmitters were set at a $30 \mathrm{~cm}$ distance (with five transmitters along the weighing lysimeter's $150 \mathrm{~cm}$ length), with a theoretical flow rate of $3.00 \mathrm{~L} \cdot \mathrm{h}^{-1}$ (sandy clay loam soil). 
When transferring variations in weight to the flow released by drips, the irrigation time, the number of drips inside the lysimeter, and the water density were taken into account. The practical flow variable of drip, $q_{p}$, is expressed in $\mathrm{L} \cdot \mathrm{h}^{-1}$.

$$
q_{p}\left(\frac{L}{h \cdot \text { transmitter }}\right)=\frac{\frac{C T_{a p}(g)}{10(\mathrm{~min})} \cdot \frac{1(\mathrm{~L})}{1000(\mathrm{~g})} \cdot \frac{60(\mathrm{~min})}{1(\mathrm{~h})}}{5(\text { transmitter })}
$$

In order to confirm that the flow that was estimated with the data obtained in the weighing lysimeter and adjusted to the theoretical transmitters' flow corresponded to reality, a manual test on one transmitter was performed. This test provided a volume. To translate it into the transmitter's flow, it was related to the time that the test lasted by defining the manual flow variable $\left(q_{m}\right)$, expressed in $\mathrm{L} \cdot \mathrm{h}^{-1}$.

$$
q_{m}\left(\frac{L}{h \cdot \text { transmitter }}\right)=\frac{\frac{\text { volume }(L)}{25(\text { min })} \cdot \frac{60(\mathrm{~min})}{1(h)}}{1(\text { transmitter })}
$$

In order to validate that the redesigned structure is capable of quantifying the water balance, a function for which it was conceived, the results obtained in two tests were compared.

Thus, first of all, the data were obtained in a test developed in Aguaderas, T.M. de Lorca (Murcia, Spain) with a Naxos-variety broccoli crop that was transplanted on 12 March 2020, and had its last harvest day on 1 June 2020, obtaining a cultivation cycle of 82 days. The crop had plastic mulch. Data obtained with the weighing lysimeter (which offers the weight variation of the culture container) on several specific days were contrasted with the reference evapotranspiration offered through the network of meteorological stations of the SIAM (Agricultural Information System of Murcia) of IMIDA (Agrarian and Food Research and Development Institute of Murcia, Spain). The data of variations in the weight of the culture container on days in which there were no drainage or contributions of water by irrigation or precipitation were related to the lysimeter's surface of influence. The surface of the cultivation tank was $150 \mathrm{~cm}$ long by $45 \mathrm{~cm}$ wide, while the culture had a separation between lines of $90 \mathrm{~cm}$; thus, given that the lysimeter supported and monitored plants whose evaporative condition corresponded to $90 \mathrm{~cm}$, it was considered that the lysimeter's surface of influence $\left(\mathrm{CI}_{\text {surface }}\right)$ was $150 \mathrm{~cm}$ long by $90 \mathrm{~cm}$ wide, resulting in $1.35 \mathrm{~m}^{2}$. Since the soil was mulched, the evaporation component of the $45 \mathrm{~cm}$ not monitored through the lysimeter could be neglected. This surface was important for transferring the units of grams to the magnitude of the height of the water sheet.

The data obtained in the weighing lysimeter correspond to the result of the following equation.

$$
E T_{a}=E T_{0} \cdot K_{c}
$$

$E T_{0}$ : Reference evapotranspiration-obtained from the SIAM—which comes from the Penman-Monteith-FAO equation and is expressed in $\mathrm{mm}$.

$K_{c}$ : Crop coefficient, which depends on specific edaphoclimatic conditions, cultural work, variety, phenological state, etc., and which corrects the reference evapotranspiration value to estimate the evapotranspiration of a given crop.

As a result:

$E T_{a}$ : This is the actual evapotranspiration according to Sánchez et al. [26]. The values relative to the weight variation of the culture container in a weighing lysimeter after considering the water inputs from irrigation or rain and the losses from deep percolation reflect the result of this actual evapotranspiration. Thus, if the weight variation in the 
culture container (expressed in mm of the water sheet) is compared with the reference evapotranspiration, the $K_{c}$ coefficient is obtained:

$$
\frac{\Delta C T\left(\frac{K g}{\text { day }}\right) \cdot \frac{1}{\rho}\left(\frac{L}{K g}\right) \cdot \frac{1}{C I_{\text {surface }}}\left(\frac{1}{m^{2}}\right) \cdot \frac{1}{1}\left(\frac{m m}{\frac{L}{m^{2}}}\right)}{E T_{0}\left(\frac{m m}{\text { day }}\right)}=K_{c}
$$

$\triangle C T$ : Variation in the cultivation tank's weight.

$\rho$ : Water density.

$C I_{\text {surface }}$ : Weighing lysimeter's surface of influence.

\section{Results}

\subsection{Dimensions Set for the Cultivation Tank}

With respect to production, the crops selected in this study are relative important, as they make up $95 \%$ of all the vegetable products grown in the Murcia Region (Spain). Although these crops are not so extensively grown in neighbouring regions, their production represents more than $60 \%$ of all of their vegetable production. So, our analysis, which aimed to suitably size the portable weighing lysimeter's $\mathrm{CT}$, is very useful because, in commercial terms, this equipment is extremely versatile for such crops and, by extension, for herbaceous crops. Moreover, this type of tool is widely accepted in the vegetable market.

After considering the study and calculations that were performed, the dimensions set for the CT were defined as $45 \mathrm{~cm}$ inner width, $150 \mathrm{~cm}$ inner length, and a mean depth of $47.5 \mathrm{~cm}$, with a minimum of $45 \mathrm{~cm}$ on its perimeter and a maximum of $50 \mathrm{~cm}$ in the centre (the point where deep percolation drains to the DT) (Figure 5).
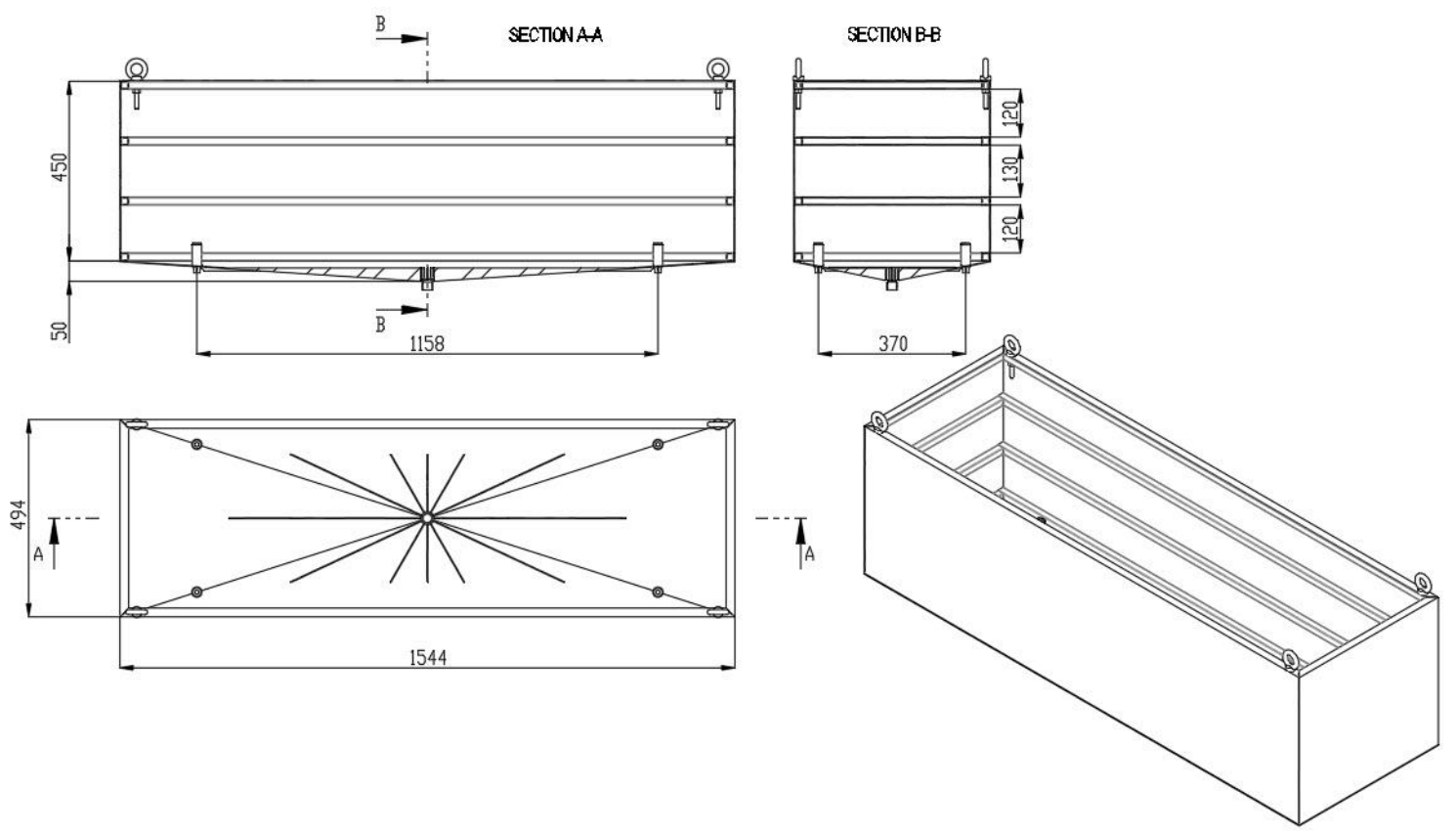

Figure 5. Cultivation tank (CT) dimensions.

\subsection{Validating the Weighing System}

The data obtained in order to calculate each transmitter's practical flow on the seven study days with the pepper crops are shown in Tables 7 and 8 . 
Table 7. Calculating transmitters' practical flow using lysimeter data.

\begin{tabular}{cccccc}
\hline Date & Start Time & End Time & Irrigation Time & $\mathbf{C T}_{\mathbf{a p}}(\mathbf{g})$ & $\mathbf{q}_{\mathbf{p}}(\mathbf{L} \cdot \mathbf{h}-\mathbf{1})$ \\
\hline 17 September 2020 & $8: 30$ & $8: 40$ & $0: 10$ & 2500 & 3.00 \\
22 September 2020 & $8: 30$ & $8: 40$ & $0: 10$ & 2500 & 3.00 \\
24 September 2020 & $8: 30$ & $8: 40$ & $0: 10$ & 2517 & 3.02 \\
26 September 2020 & $8: 30$ & $8: 40$ & $0: 10$ & 2533 & 3.04 \\
30 September 2020 & $8: 35$ & $8: 45$ & $0: 10$ & 2517 & 3.02 \\
02 October 2020 & $8: 35$ & $8: 45$ & $0: 10$ & 2492 & 2.99 \\
06 October 2020 & $8: 35$ & $8: 45$ & $0: 10$ & 2500 & 3.00 \\
Average & & & & 2508 & 3.01 \\
\hline
\end{tabular}

Table 8. Calculating manual transmitters' flow using manual test data.

\begin{tabular}{|c|c|c|c|c|c|c|}
\hline Transmitter Number & Date & Start Time & End Time & Irrigation Time & Collected Volume (L) & $q_{m}\left(L \cdot h^{-1}\right)$ \\
\hline 1 & 14 October 2020 & $8: 45$ & 9:10 & $0: 25$ & 1.20 & 2.88 \\
\hline 2 & 14 October 2020 & $8: 45$ & 9:10 & $0: 25$ & 1.22 & 2.93 \\
\hline 3 & 14 October 2020 & $8: 45$ & 9:10 & $0: 25$ & 1.21 & 2.90 \\
\hline 4 & 14 October 2020 & $8: 45$ & 9:10 & $0: 25$ & 1.18 & 2.83 \\
\hline 5 & 14 October 2020 & $8: 45$ & $9: 10$ & $0: 25$ & 1.19 & 2.86 \\
\hline \multicolumn{5}{|c|}{ Average } & 1.20 & 2.88 \\
\hline
\end{tabular}

Figure 6 shows the results for the $\mathrm{K}_{\mathrm{c}}$ at different times during the broccoli crop cycle using the designed lysimeter $\left(\mathrm{K}_{\mathrm{c}}\right.$ lysimeter) in comparison with the theoretical values found using published data from the studies of Rubino et al. [43] and Villalobos-Reyes et al. [44] and with the FAO-56 data [45].

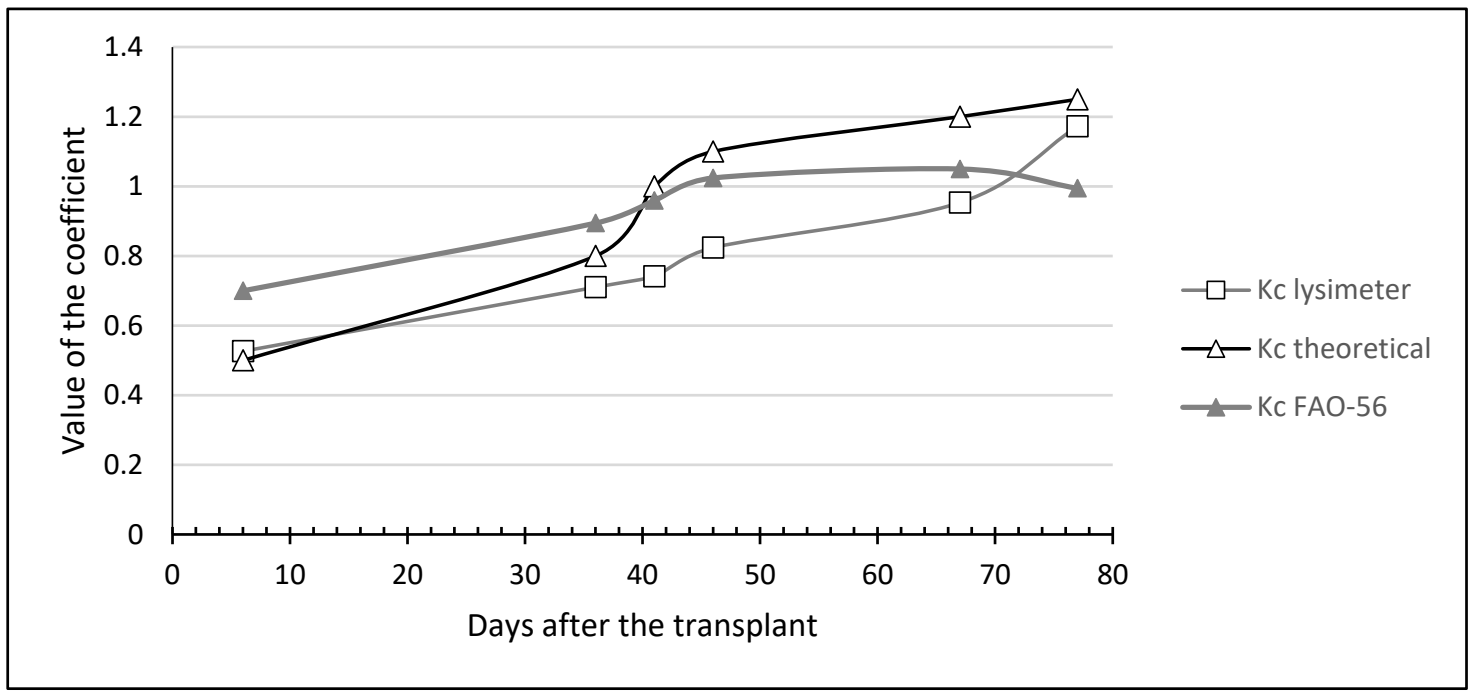

Figure 6. Comparison of the product of the $\mathrm{K}_{\mathrm{c}}$ coefficient lysimeter with the theoretical cultivation Kc coefficient for broccoli found through weighing lysimetry, as well as from the studies of Rubino et al. [43] and Villalobos-Reyes et al. [44] and with the FAO-56 data [45].

\section{Discussion}

Table 4 summarises the taxonomic and agronomic characteristics of the studied crops. With planting frames, the frame choice depends on many factors, but, except for watermelon crops, two or more plants of the other crops can be grown inside a lysimeter, which allows suitable representativeness.

Although the root depth varies according to the crop, the active zone is always in the upper soil layers [46]. Thus, the depth with which the CT was designed allows practically 
the whole root volume to be housed, and the crop inside is exposed to similar conditions to those outside the lysimeter.

The standardization of production systems and their mechanisation allow the portable weighing lysimetry equipment to be set up similarly to the equipment developed by the Agromotic Engineering and Sea Research Group of the Universidad Politécnica de Cartagena (Spain). This is enabled by it being perfectly integrated into crop lines, on narrow crop beds (Figure 1) or wide crop beds (Figure 2), or when crops are grown flat (Figure 3).

After analysing the loads that could support the equipment by means of the $\mathrm{CT}$, it was deduced that increasing the depth was counterproductive because it limited the nominal capacity of the load cells to be used, which would reduce the equipment's resolution.

With the dimensions indicated herein for the CT, a crop surface of $0.675 \mathrm{~m}^{2}$ was obtained. Compared to any other water balance estimation method-for instance, with humidity sensors [47] - this surface area is large because sensors are only able to monitor a small volume around the point where they are fitted. In addition, portable weighing lysimetry equipment quantifies, rather than estimates, water balance components because it quantifies and qualifies deep percolation drainage. It also quantifies water inputs due to irrigation and precipitation as well as losses through evapotranspiration.

Depending on the type of load cell being used, resolutions between 0.09 and $0.15 \mathrm{~mm}$ can be accomplished. End users can obtain the resolution that they are interested in at the same weighing lysimetry equipment cost. For example, if the equipment is to be used for research purposes, the load cell to be fitted can be one with $300 \mathrm{~kg}$ of nominal capacity, which gives a resolution of $0.09 \mathrm{~mm}$. However, for commercial farming, the equipment management conditions are not the same because the personnel who perform cultivation tasks do not necessarily have to be specifically trained in handling this equipment, and they might sporadically apply loads that can harm $300 \mathrm{~kg}$ load cells. Therefore, for commercial farming, fitting $500 \mathrm{~kg}$ load cells will guarantee that the equipment lasts, but with a $0.15 \mathrm{~mm}$ resolution. Nonetheless, considering that the reference evapotranspiration can be of the order of 6-7 mm, accurate irrigation can be achieved at the obtained resolution.

The resolution is conditioned by the sampling surface. Generally, for crops with limited growth habits, the calculated surface area of $0.675 \mathrm{~m}^{2}$ is that which the weighing lysimeter actually monitors. However, for crops with more expansive growth habits or creeping crops, such as melon and even watermelon, which can cover a $4 \mathrm{~m}^{2}$ surface area, the measurements taken by the lysimeter do not only affect a surface area of $0.675 \mathrm{~m}^{2}$. The plant, which covers a much greater surface than that of the $\mathrm{CT}$, draws water from inside the lysimeter. So, the resolution value is significantly reduced. In commercial terms, where the surface area used is important, the data obtained with the weighing lysimeter can provide irrigation recommendations. Instead of being expressed as water lamina, they are expressed as water volume per plant, which is more representative and can be perfectly extrapolated to the interior of the monitored farmland.

For all these reasons, the dimensions of the portable weighing lysimetry equipment are suitable, and it accurately manages irrigation thanks to the high resolution that it offers. If we consider its fitted sensors for quantifying and qualifying deep percolation drainage (a load cell for the DT and an electric conductivity sensor inside it), nutrition can also be managed. By adding another conductivity sensor to the irrigation line, irrigation and fertilisation can also be managed to avoid saline concentration in the humid bulb. The equipment has a tank for taking samples to sporadically test irrigation water, drained water, and even soil and plant material in order to know and correct the nutrient balance [16].

After checking the weighing system by analysing a set of five transmitters that poured onto the lysimeter at a theoretical flow of $3.00 \mathrm{~L} \cdot \mathrm{h}^{-1}$, according to Table 7 , we confirmed that the equipment recorded this pluviometry value for each transmitter at a mean rate of $3.01 \mathrm{~L} \cdot \mathrm{h}^{-1}$. To confirm that the measurement was correct, a manual test was performed, which, according to Table 8 , gave a flow of $2.88 \mathrm{~L} \cdot \mathrm{h}^{-1}$. We should bear in mind that the accuracy of the measurements in terms of time and obtained volume was much lower in 
this manual test than for the data provided by the weighing lysimeter. So, the sampling time was prolonged to minimise the time measurement error and, thus, to increase the obtained volume to minimise mistakes in the measurements. Nonetheless, this lower precision may have led to the observed differences; thus, the weighing system is believed to operate suitably.

On the other hand, the values of the Kc coefficient lysimeter in the broccoli test using the standard weighing lysimeter were compared with the theoretical Kc obtained for this crop with a weighing lysimeter in the studies of Rubino et al. [43] and VillalobosReyes et al. [44]. In general, the values obtained in our validation are similar to the values of these studies, which allows us to confirm that the measurements of the standard weighing lysimeter are valid for the main function for which it was designed, which is the control of the water balance of vegetable and herbaceous crops. The obtained results were also compared with the FAO-56 data [45], which show that the cultivation cycle proposed for broccoli (Table 11 of FAO-56 for these specific conditions) is 135 days. The cultivation cycle of the test carried out in this study was 82 days, so the cultivation stages proposed by FAO-56 were reduced proportionally. The Kc coefficients proposed by FAO-56 (Table 12 of FAO-56) were used, and they are similar to those obtained with the other two methods, which are reflected in Table 6 of FAO-56. These results can also confirm the validity of the measurements provided for the standard weighing lysimeter.

In any case, in order to automate irrigation operations, it is more useful to derive the lysimeter data directly in litres per plant so that irrigation scheduling can be directly adjusted according to the real-time water use determinations without the need for separately computing the reference evapotranspiration.

\section{Conclusions}

A weighing lysimeter that is supported by information and communication technologies can be an effective tool for achieving efficient water and nutrient management. The dimensions of the CT of the portable weighing lysimeter developed by the Agromotic Engineering and Sea Research Group (Universidad Politécnica de Cartagena, Spain) allow it to be used for the monitoring of practically all vegetable crops and, by extension, herbaceous crops, as it adapts to a wide range of production and mechanisation systems. The possibilities of manufacturing it with different resolutions at the same cost allow adaptations to be made to lysimetry stations for research $(0.09 \mathrm{~mm}$ resolution with $300 \mathrm{~kg}$ load cells) or to commercial lysimetry stations $(0.15 \mathrm{~mm}$ resolution with $500 \mathrm{~kg}$ load cells). The possibility of quantifying and qualifying deep percolation drainage-and even of taking deep percolation drainage samples - allows accurate management of not only crop irrigation, but also crop fertilisation. After analysing the CT's weighing system, its performance was found to be suitable, and its results corresponded to reality. Therefore, this portable weighing lysimeter is suitable for accurately measuring the use of water and nutrients in crops.

Author Contributions: Conceptualization, M.S.-M.; methodology, M.S.-M. and D.P.-B.; software, D.P.-B.; validation, D.S.I., A.R.-C., and J.M.M.-M.; formal analysis, M.S.-M.; investigation, M.S.-M., D.P.-B., and E.M.-E.; resources, A.R.-C. and J.M.M.-M.; data curation, M.S.-M. and E.M.-E.; writingoriginal draft preparation, M.S.-M. and D.P.-B.; writing-review and editing, D.S.I., A.R.-C., and J.M.M.-M.; visualization, D.P.-B.; supervision, D.S.I. and J.M.M.-M.; project administration, funding acquisition, M.S.-M. and J.M.M.-M. All authors have read and agreed to the published version of the manuscript.

Funding: Research and development project with reference IDI-20190146, entitled "Development and implementation of a weighing lysimeter ferticontrol equipment for use in intensive agriculture", in collaboration with the company AGROSOLMEN, S.L., co-financed by the European Regional Development Fund (FEDER) through the Spanish Multiregional Operational Programme 2014-2020. Preciriego (RTC-2017-6365-2) project co-financed by FEDER and AEI-Spain.

Institutional Review Board Statement: Not applicable.

Informed Consent Statement: Not applicable. 
Data Availability Statement: Data is contained within the article.

Conflicts of Interest: The authors declare no conflict of interest.

\section{References}

1. Figures for the Fruit and Vegetable Sector (In Spanish). Ministry of Agriculture, Fisheries and Food (Spain). Available online: https:/ / www.mapa.gob.es/es/agricultura/temas/producciones-agricolas / cifras_del_sectorfyh_tcm30-502367.pdf (accessed on 10 January 2020).

2. Southeast Spain: Leader in National Fruit and Vegetable Production (In Spanish). Available online: http:/ / www.trasvasetajosegu ra.com/la-region-del-segura-lider-de-la-produccion-nacional-de-frutas-y-hortalizas/ (accessed on 10 January 2020).

3. Salehpour, T.; Khanali, M.; Rajabipour, A. Environmental impact assessment for ornamental plant greenhouse: Life cycle assessment approach for primrose production. Env. Pollut. 2020, 266, 115258. [CrossRef] [PubMed]

4. Sanchez-Sastre, L.F.; Da Veiga, N.; Ruiz-Potosme, N.M.; Hernandez-Navarro, S.; Marcos-Robles, J.L.; Martin-Gil, J.; Martin-Ramos, P. Sugar Beet Agronomic Performance Evolution in NW Spain in Future Scenarios of Climate Change. Agron. (Basel) 2020, 10, 91. [CrossRef]

5. Diouf, J. Agriculture to 2050: The Challenges Ahead. Food and Agriculture Organization of the United Nations (FAO). Available online: http:/ / www.fao.org/news/story/en/item/36193/icode/ (accessed on 3 October 2020).

6. What is Precision Agriculture? (In Spanish). Available online: https://agro.iberf.es/que-es-la-agricultura-de-precision/ (accessed on 11 January 2020).

7. Daum, T. ICT Applications in Agriculture. In Encyclopedia of Food Security and Sustainability; Reference Module in Food Science; Elsevier: Amsterdam, The Netherlands, 2019; Volume 1, pp. 255-260.

8. Escarabajal-Henarejos, D.; Molina-Martínez, J.; Fernández-Pacheco, D.; Cavas-Martínez, F.; García-Mateos, G. Digital photography applied to irrigation management of Little Gem lettuce. Agric. Water Manag. 2015, 151, 148-157. [CrossRef]

9. Ferrández-Villena, M.; Ruiz-Canales, A. Advances on ICTs for water management in agriculture. Agric. Water Manag. 2017, 100, 1-3. [CrossRef]

10. González-Esquiva, J.; García-Mateos, G.; Escarabajal-Henarejos, D.; Hernández-Hernández, J.; Ruiz-Canales, A.; Molina-Martínez, J. A new model for water balance estimation on lettuce crops using effective diameter obtained with image analysis. Agric. Water Manag. 2017, 183, 116-122. [CrossRef]

11. Jiménez-Buendía, M.; Ruiz-Peñalver, L.; Vera-Repullo, J.; Intrigliolo-Molina, D.; Molina-Martínez, J. Development and assessment of a network of water meters and rain gauges for determining the water balance. New SCADA monitoring software. Agric. Water Manag. 2015, 151, 93-102. [CrossRef]

12. Sahu, B.; Chatterjee, S.; Mukherjee, S.; Sharma, C. Tools of precision agriculture: A review. Int. J. Chem. Stud. 2019, 7, 2692-2696.

13. Vera-Repullo, J.; Ruiz-Peñalver, L.; Jiménez-Buendía, M.; Rosillo, J.; Molina-Martínez, J. Software for the automatic control of irrigation using weighing-drainage lysimeters. Agric. Water Manag. 2015, 151, 4-12. [CrossRef]

14. Ajaz, A.; Datta, S.; Stoodley, S. High Plains Aquifer-State of Affairs of Irrigated Agriculture and Role of Irrigation in the Sustainability Paradigm. Sustainability 2020, 12, 3714. [CrossRef]

15. Aboukhaled, A.; Smith, M. Lysimeters; Food \& Agriculture Organization: Rome, Italy, 1986; Volume 39.

16. Hirschi, M.; Michel, D.; Lehner, I.; Seneviratne, S.I. A site-level comparison of lysimeter and eddy covariance flux measurements of evapotranspiration. Hydrol. Earth Syst. Sci. 2017, 21, 1809-1825. [CrossRef]

17. Howell, T.A.; Schneider, A.D.; Jensen, M.E. History of lysimeter design and use for evapotranspiration measurements. In Lysimeters for Evapotranspiration and Environmental Measurements; ASCE: Reston, VA, USA, 1991; pp. 1-9.

18. Soler-Méndez, M.; Madrona-Sánchez, P.; Ávila-Dávila, L.; Ruíz-Canales, A.; Molina-Martínez, J.M. Analysis of Water Consumption of Hordeum vulgare L. by Means of a Lysimetric Weighing Equipment. In Proceedings of the X Congreso de Agroingeniería, Huesca, Spain, 3-6 September 2019. (In Spanish).

19. Liu, S.; Bai, J.; Jia, Z.; Jia, L.; Zhou, H.; Lu, L. Estimation of evapotranspiration in the Mu Us Sandland of China. Hydrol. Earth Syst. Sci. 2010, 14, 573. [CrossRef]

20. López-Urrea, R.; De Santa Olalla, F.M.; Fabeiro, C.; Moratalla, A. Testing evapotranspiration equations using lysimeter observations in a semiarid climate. Agric. Water Manag. 2006, 85, 15-26. [CrossRef]

21. Liu, C.; Cui, N.; Gong, D.; Hu, X.; Feng, Y. Evaluation of seasonal evapotranspiration of winter wheat in humid region of East China using large-weighted lysimeter and three models. J. Hydrol. 2020, 590, 125388. [CrossRef]

22. Liu, X.; Xu, C.; Zhong, X.; Li, Y.; Yuan, X.; Cao, J. Comparison of 16 models for reference crop evapotranspiration against weighing lysimeter measurement. Agric. Water Manag. 2017, 184, 145-155. [CrossRef]

23. López-Urrea, R.; Sánchez, J.; De la Cruz, F.; González-Piqueras, J.; Chávez, J. Evapotranspiration and crop coefficients from lysimeter measurements for sprinkler-irrigated canola. Agric. Water Manag. 2020, 239, 106260. [CrossRef]

24. Montoro, A.; Torija, I.; Mañas, F.; López-Urrea, R. Lysimeter measurements of nocturnal and diurnal grapevine transpiration: Effect of soil water content, and phenology. Agric. Water Manag. 2020, 229, 105882. [CrossRef]

25. Rafi, Z.; Merlin, O.; Le Dantec, V.; Khabba, S.; Mordelet, P.; Er-Raki, S.; Amazirh, A.; Olivera-Guerra, L.; Hssaine, B.A.; Simonneaux, V. Partitioning evapotranspiration of a drip-irrigated wheat crop: Inter-comparing eddy covariance-, sap flow-, lysimeter-and FAO-based methods. Agric. For. Meteorol. 2019, 265, 310-326. [CrossRef] 
26. Sánchez, J.M.; López-Urrea, R.; Valentín, F.; Caselles, V.; Galve, J.M. Lysimeter assessment of the Simplified Two-Source Energy Balance model and eddy covariance system to estimate vineyard evapotranspiration. Agric. For. Meteorol. 2019, 274, 172-183. [CrossRef]

27. Zheng, W.; Wan, Y.; Li, Y.; Liu, Z.; Chen, J.; Zhou, H.; Gao, Y.; Chen, B.; Zhang, M. Developing water and nitrogen budgets of a wheat-maize rotation system using auto-weighing lysimeters: Effects of blended application of controlled-release and un-coated urea. Environ. Pollut. 2020, 114383. [CrossRef] [PubMed]

28. Jiménez-Carvajal, C.; Ruiz-Peñalver, L.; Vera-Repullo, J.; Jiménez-Buendía, M.; Antolino-Merino, A.; Molina-Martínez, J. Weighing lysimetric system for the determination of the water balance during irrigation in potted plants. Agric. Water Manag. 2017, 183, 78-85. [CrossRef]

29. Nicolás-Cuevas, J.A.; Parras-Burgos, D.; Ruiz-Canales, A.; Molina-Martínez, J.M. Real-Time Modular Remote Management System for the Vegetative State of Crops, Water and Nutrients Consumption. Patent Number ES 2668210 B2, 16 November 2018.

30. Nicolás-Cuevas, J.A.; Parras-Burgos, D.; Soler-Méndez, M.; Ruiz-Canales, A.; Molina-Martínez, J.M. Removable Weighing Lysimeter for Use in Horticultural Crops. Appl. Sci. 2020, 10, 4865. [CrossRef]

31. Ruiz-Peñalver, L.; Vera-Repullo, J.; Jiménez-Buendía, M.; Guzmán, I.; Molina-Martínez, J. Development of an innovative low cost weighing lysimeter for potted plants: Application in lysimetric stations. Agric. Water Manag. 2015, 151, 103-113. [CrossRef]

32. Regional Agricultural Statistics of the Ministry of Agriculture, Livestock and Fisheries of the Autonomous Community of the Region of Murcia (Spain). Available online: https:/ /www.carm.es/web/pagina?IDCONTENIDO=2589\&IDTIPO=100\&RASTR $\mathrm{O}=\mathrm{c} 80 \$ \mathrm{~m} 22721,22746,1174$ (accessed on 3 October 2020).

33. Annual Crop Areas and Yields. Main Results. Available online: http://pegv.gva.es/es/temas/agriculturaganaderiaselviculturac azapescayacuicultura/agricultura/superficiesyproduccionesanualesdecultivo (accessed on 3 October 2020). (In Spanish).

34. Reports on Agricultural Production. Available online: http://www.ies.jccm.es/estadisticas/por-tema/sectores-economicos/agri cultura / (accessed on 3 October 2020).

35. Andalusian Agricultural and Fishing Statistics Yearbook. Available online: https://www.juntadeandalucia.es/organismos/a griculturaganaderiapescaydesarrollosostenible/servicios/estadistica-cartografia/anuarios.html (accessed on 3 October 2020). (In Spanish).

36. Crops InfoAgro.com. Available online: https://www.infoagro.com/hortalizas/hortalizas.htm (accessed on 3 October 2020). (In Spanish).

37. Artichoke, Cynara Scolymus/Compositae (Asteraceae). Fruit and Vegetables. Available online: https://www.frutas-hortalizas. com/Hortalizas/Presentacion-Alcachofa.html (accessed on 1 October 2020). (In Spanish).

38. Abarca, P. Agronomic Management Manual for Watermelon Cultivation; INIA: Madrid, Spain, 2017; ISSN 0717-4829. Available online: https:/ / www.inia.cl/wp-content/uploads/ManualesdeProduccion/02\%20Manual\%20Sandia.pdf (accessed on 3 October 2020). (In Spanish)

39. Abarca, P. Agronomic Management Manual for Melon Cultivation; INIA: Madrid, Spain, 2017; ISSN 0717-4829. Available online: https://www.inia.cl/wp-content/uploads/ManualesdeProduccion/01\%20Manual\%20melon.pdf (accessed on 3 October 2020). (In Spanish)

40. Reche Mármol, J. Intensive Cultivation of Courgette; Information Sheets; Ministerio de Agricultura, Pesca y Alimentación: Madrid, Spain, 2000. Available online: https:/ / www.olivosdebadajoz.com/PLANTAS-DE-HORTALIZA/Calabacin.pdf (accessed on 3 October 2020). (In Spanish)

41. Sangiacomo, M.Á.; Garbi, M.; Puerta, A.; Garcia, L.; Gómez, D.; Oyhantos, F. Depth of the Root of the Vegetables. Vegetable Production Group. National University of Luján (Argentina). Available online: http:/ /www.hort.unlu.edu.ar/sites/www.hort. unlu.edu.ar/files/site/Profundidad\%20de\%20raices.pdf (accessed on 5 October 2020). (In Spanish).

42. FAO Soils Portal. Physical properties. Food and Agriculture Organization of the United Nations (FAO). Available online: http:/ / www.fao.org/soils-portal/soil-survey/soil-properties/physical-properties/en/ (accessed on 7 October 2020).

43. Rubino, P.; De Palma, E. Determinazione dei fabbisogni idrici del cavolo broccolo (Brassica oleracea L. var. italica Plenk) con lisimetro a pesata. Riv. Irrig. E Dren. 1989, 36, IV/5-IV/8.

44. Villalobos-Reyes, S.; Castellanos-Ramos, J.Z.; Tijerina-Chávez, L.; Crespo-Pichardo, G. Coeficientes de desarrollo del cultivo de brócoli con riego por goteo (Crop Coefficient in Broccoli under Drip Irrigation). Terra Latinoam. 2005, 23, 329-333. Available online: https: / / www.redalyc.org/pdf/573/57311101004.pdf (accessed on 3 October 2020).

45. Allen, R.G.; Pereira, L.S.; Raes, D.; Smith, M. Crop evapotranspiration. In Guidelines for Computing Crop Water Requirements; FAO Irrigation and Drainage Paper 56; FAO: Rome, Italy, 1998; Available online: http:/ /www.fao.org/3/X0490E/X0490E00.htm (accessed on 3 October 2020).

46. Zinkernagel, J.; Maestre-Valero, J.F.; Seresti, S.Y.; Intrigliolo, D. New technologies and practical approaches to improve irrigation management of open field vegetable crops. Agric. Water Manag. 2020, 242, 106404. [CrossRef]

47. Alonso López, F.; Contreras París, J.I.; Gavilán Zafra, P.; Baeza Cano, R. Management of Automated Irrigation with Tensiometers in Horticultural Crops in Almeria. In Proceedings of the VI Conference on Agrometeorology, Villava, Spain, 17-18 November 2016. (In Spanish). 